\title{
(In)visibility of children with special health needs and their families in primary care
}

\author{
(In)visibilidade de crianças com necessidades especiais de saúde e suas famílias na atenção primária \\ (In)visibilidad de niños con necesidades especiales de salud y sus familias en la atención primaria
}

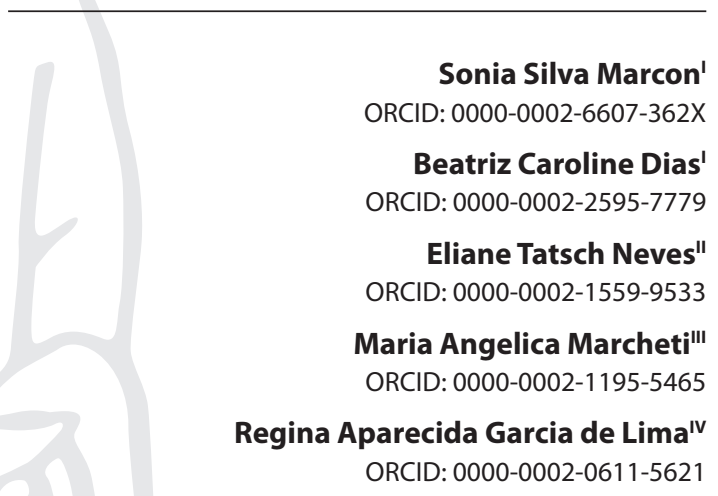

'Universidade Estadual de Maringá. Maringá, Paraná, Brazil. "Universidade Federal de Santa Maria. Santa Maria,

Rio Grande do Sul, Brazil.

I'Universidade Federal de Mato Grosso do Sul. Campo Grande, Mato Grosso do Sul, Brazil.

"Universidade de São Paulo. Ribeirão Preto, São Paulo, Brazil.

How to cite this article:

Marcon SS, Dias BC, Neves ET, Marchetti MA Lima RAG. (In)visibility of children with special health needs and their families in primary care.

Rev Bras Enferm. 2020;73(Suppl 4):e20190071. doi: http://dx.doi.org/10.1590/0034-7167-2019-0071

\section{Corresponding author:}

Sonia Silva Marcon

E-mail: soniasilva.marcon@gmail.com

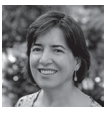

EDITOR IN CHIEF: Antonio José de Almeida Filho ASSOCIATE EDITOR: Priscilla Valladares Broca

Submission: 02-04-2019

Approval: 04-29-2020

\section{ABSTRACT}

Objectives: to discuss the (in)visibility of children with special healthcare needs and their families in the Primary Health Care scenario. Methods: experience report about the difficulties faced by researchers from different regions of Brazil to locate children with special healthcare needs in the scope of primary care. Results: the main reason for these children and their families to be "unknown" and, therefore, not assisted in PHC, is the fact that they are followedup by institutions/outpatient clinics and specialized and/or public rehabilitation clinics, or even because they have private health insurance. Final Considerations: transferring care responsibility to the Primary Health Care teams to specialized and rehabilitation institutions may be related to the lack of knowledge of the care demands of this group, as well as to the relevance of care centered on rehabilitation and the specialty instead of the long-term care, one of the features of primary health care.

Descriptors: Children; Primary Health Care; Family; Long-Term Care; Chronic Disease

\section{RESUMO}

Objetivos: discutir a (in)visibilidade de crianças com necessidades especiais de saúde e suas famílias no contexto da Atenção Primária à Saúde. Métodos: relato de experiência acerca das dificuldades enfrentadas por pesquisadoras de diferentes regiões do Brasil para localizar crianças com necessidades especiais de saúde no âmbito da atenção primária. Resultados: a principal justificativa para essas crianças e suas famílias serem "desconhecidas" e, por conseguinte, não assistidas na atenção primária, é o fato de serem acompanhadas por instituições/ambulatórios e clínicas especializadas e/ou de reabilitação públicas, ou ainda, por terem plano de saúde privado. Considerações Finais: a transferência de responsabilidade do cuidado das equipes da atenção primária para instituições especializadas e de reabilitação pode estar relacionada à falta de conhecimento das demandas de cuidados deste grupo, bem como à valorização do cuidado centrado na reabilitação e na especialidade em detrimento da longitudinalidade do cuidado, um dos atributos da atenção primária à saúde. Descritores: Crianças; Atenção Primária à Saúde; Família; Longitudinalidade do Cuidado; Doença Crônica.

\section{RESUMEN}

Objetivos: discutir la (in)visibilidad de los niños con necesidades especiales de salud y sus familias en el contexto de la Atención Primaria de Salud. Métodos: informe de experiencia sobre las dificultades que enfrentan los investigadores de diferentes regiones de Brasil para localizar a niños con necesidades especiales de salud en el ámbito de la atención primaria. Resultados: la principal justificación para que estos niños y sus familias sean "desconocidos" $y$, por lo tanto, no reciban asistencia en la Atención Primaria de Salud, es el hecho de que son tratados por instituciones/ clínicas ambulatorias y clínicas especializadas y/o rehabilitación pública, o porque tienen plan de salud privado. Consideraciones Finales: la transferencia de la responsabilidad por la atención de los equipos de Atención Primaria de Salud a las instituciones especializadas y de rehabilitación puede ter relación con la falta de conocimiento de las demandas de atención de este grupo, y con la valorización de la atención centrada en la rehabilitación y la especialidad, en detrimento de la longitudinalidad de la atención, uno de los atributos de la Atención Primaria de Salud. Descriptores: Niños; Atención Primaria de Salud; Familia; Continuidad de la Atención al Paciente; Enfermedad Crónica. 


\section{INTRODUCTION}

With the change in the epidemiological profile of health problems in early childhood, an increase in the number of children who survive with special healthcare needs (CSHN), that is, who demand care beyond those required by others in this age group, is emerging. Such care can be developmental, technological, medication and/or usual modified care ${ }^{(1)}$.

In Brazil, the National Primary Care Policy (PNAB) recommends health actions at the individual and collective levels, focusing on family health care in a decentralized manner, to enable access to the entire population. Thus, the Family Health Strategy (FHS), which is responsible for organizing and coordinating the interaction between all health services, has the prerogative to ensure the principle of comprehensive care ${ }^{(2-3)}$. Contradictorily, in many realities, the organization of health services is defined by intense fragmentation and the current care model does not correspond to changes in the epidemiological profile of the Brazilian population, given the rise of chronic diseases ${ }^{(3)}$.

It is in this scenario of disarticulation that CSHN and their families are inserted. Regarding the scope of primary care, the precarious structure to receive them and the lack of home care stand out ${ }^{(4)}$. Added to this, the daily struggle faced by these families to ensure the rights of their children, in the face of a fragile and disjointed care network ${ }^{(5)}$.

\section{OBJECTIVES}

To discuss the (in)visibility of children with special healthcare needs and their families in the Primary Health Care scenario.

\section{METHODS}

This is an experience report developed based on situations experienced by nurse researchers from different regions of the country when seeking to identify and contact CSHN within the scope of Primary Health Care (PHC) for the development of research. It should be noted that, initially, the researchers experienced this difficulty in isolation, as a specific reality of the municipalities where the studies were carried out. However, when discussing the results of their studies in scientific events and presentation of thesis and dissertation to board members, they found similarities of difficulties and challenges faced - in different scenarios and regions of the country - to locate this clientele within the PHC scope. Thus, they realized the need to report their experiences to discuss the issue, giving visibility to it.

In methodological terms, first, all the researchers reported and converged their main difficulties in identifying CSHN and their families within the PHC scope, their strategies to locate them and, after finding them, what were the main reports presented regarding the care received. Subsequently, they discussed the impact of the lack of follow-up in $\mathrm{PHC}$, as well as proposed measures to bring sense to managers and health professionals about the importance of these children and their families being assisted, monitored and supported at this level of care in favor of integrality, longitudinal and equity care.

It is noteworthy that the results reported here come from studies carried out with CSHN independently in the course of the development of research projects in the municipalities of Maringá-PR, Santa Maria-RS, Ribeirão Preto-SP and Campo Grande-MS. All of the studies were submitted to the Research Ethics Committee of their respective institutions, in compliance with Resolution 466/2012 of the National Health Council.

\section{RESULTS}

\section{Strategies to identify children with special health needs in primary care}

In PHC, there is no systematic method for the registration of CSHN that makes it possible to know how many and where these children and their families are placed, since the registration and monitoring forms of families in primary care (Primary Care Information System - SIAB) have only the indication of disability - which refers to a long-term or permanent physical or mental condition. In this way, all the researchers, in the different states of the country, went personally to the health units to talk to survey assisted CSHN. However, despite the complexity and demand for care that this population requires, it was observed that, in most cases, specific monitoring was not offered to these people in the primary care service checked for the research. Besides that, in some cases, the existence of these children was unknown in the coverage area, except for some isolated reports by community health agents who knew the population because they lived in the community.

One of the experiences took place in a study carried out in Maringá-PR ${ }^{(6)}$, in which the researchers contacted all nurses or coordinators of the 29 Basic Health Units ( $\mathrm{BHU}$ ) in the city and, also, informal conversation with community health workers(CHW) of the 62 FHS teams. At this time, they requested the indication of children residing in the area covered by the Unit who would be able to be included in the study because they have special needs for continuous/complex care.

In a study carried out in Ribeirão Preto-SP, there was also contact with $46 \mathrm{PHC}$ units in search of an indication of CSHN in the coverage area, in addition to displaying posters in the Units and dissemination in the news ${ }^{(5)}$. In the double-center study carried out in Ribeirão Preto-SP and Santa Maria-RS, after finding that professionals were unaware of these children and/or confused them with others with Down syndrome, for example, an active search was carried out with a screening of all children attended for any reason at $\mathrm{BHU}^{(7)}$. In Campo Grande - MS, due to the difficulty in spotting the CSHN in PHC, the researchers had the support of referrals made by a public hospital and a special education and rehabilitation institution ${ }^{(8)}$.

However, although communication media were used, such as folders and posters, to explain the characteristics presented by these children, the survey of the CSHN attended at the PHC was not effective, as there was little control and registration of such visits. Also, when some type of record was found, it was from the material dispensing book (diapers, probes, gauze, among others) of the warehouse. It is highlighted that the CSHN terminology, used here, has its concept in the academic group and it was detailed to professionals, aiming to explain which children could be included in this definition according to guidelines of a specific instrument for identifying this clientele, namely: to have some drug dependence for at least 12 months, need for follow-up in 
specialized services and physical limitation. If the child has at least one of these characteristics, it is considered a $\mathrm{CSHN}^{(9)}$, as it requires greater support from health care networks, educational services and social assistance.

Given these primary difficulties, the researchers established new strategies, such as, the active search in non-governmental support institutions in the municipalities of Maringá and Campo Grande and the application of the snowball method. This method was adopted in a study carried out in Ribeirão Preto and allowed the identification of 102 CSHN in that municipality.

In Maringá, the CSHN were spotted with the support of an educational and rehabilitation institution, which, in contrast to the PHC that had indicated 27 CSHN, identified 91 enrolled CSHN, showing a great discrepancy concerning the number of children monitored by the PHC. In Campo Grande, most of the spotted families attended the referral of professionals and accepted the invitation to participate in the study. Even other families, who later heard about the study, spontaneously sought information and actively participated in the activities. This shows the lack of intervention and the gap in assistance to these families.

\section{The experience of families concerning PHC services}

After facing adversities to identify CSHN in the community, the researchers finally accessed the family's experience in this type of care and identified similar reports regarding $\mathrm{PHC}$ services. The authors of the studies carried out in Ribeirão Preto and Santa Maria, for example, identified, through the reports of family members, that the CSHN were not monitored by $\mathrm{PHC}$ in a systematic way regarding the $\mathrm{PHC}$ attributes - longitudinal and coordination of care, because, many times, exactly because they had a chronic condition, they were guided to seek assistance directly in the emergency services or specialized outpatient clinics.

Likewise, the study carried out in Maringá found that of the 68 participating CSHN, 40 were not visited by any member of the FHS team, 21 were visited only by the $\mathrm{CHW}$ and only seven reported that they were, in fact, followed-up by the FHS team. Also, the reports showed that in the face of some health problems, the child was not considered a priority when scheduling medical appointments, raising the need to seek emergency care services and/or even hire private health insurance ${ }^{(6)}$.

In the study conducted in Campo Grande-MS, the interviewed families reported not using the BHU because they considered that the professionals did not direct interventions to their reality and were disinterested in their needs. They also reported that the units did not guarantee priority access due to the child's special condition and that actions directed at the child and/or the family were not developed by the team, except for immunization and general guidelines. Thus, they perceived themselves as distant from health professionals, especially from the BHU. Besides, they assessed that the information and guidance received, since the child's diagnosis, did not clarify or assist in the management of home care. According to some reports, the BHU team adopts a family responsibility attitude when the child has an aggravated health situation, which intensifies conflicts and increases the distance in the interactions between the team and the family, who do not feel supported in their challenges with the child(8).

\section{DISCUSSION}

Children included the study had chronic conditions, with important implications for their growth and development. They also needed health technologies to keep the activities of daily living, and the main caregiver usually was a member of the nuclear family, most often, the mother. Children who have progressive, incurable, disabling diseases, need continuous pediatric care, to control symptoms and ensure monitoring in psychological, emotional and spiritual aspects, including their families ${ }^{(10)}$.

It is noteworthy that the work of primary care with these families allows them to be properly guided to provide care and, consequently, to avoid health complications, in addition to promoting the use of basic assistance resources. Communication between the family and the health service to assess what are the real needs to be assisted helps in practical aspects and the elaboration of care plans, in addition to providing quality of life, despite the experience of chronicity, and assisting in case of family experience the suffering process ${ }^{(10)}$. It is noteworthy that, although it is a subject little discussed, families, in a way, already experience a process of mourning for the unhealthy child, that is, this experience is invaded by the insecurity of the longevity of the lives of children with special healthcare needs.

The little knowledge or (un)knowledge of community health workers (CHW) about these children, despite living in the area covered by their FHS team, demonstrates a failure to comply with what is recommended by the National Primary Care Policy ${ }^{(2)}$, since all families belonging to a micro area must be registered and have their records updated frequently.

In a study carried out with CHW on the perceptions about their performance in the FHS, the authors found that they did not recognize the mapping and registration of families as attributions of their position ${ }^{(11)}$. It is recommended that nurses, as one of their roles, provide comprehensive assistance to families at home when they are unable to attend the UBS ${ }^{(2)}$. It is emphasized that the recognition of the specificities of the role of each member working in the FHS is central to their performance and ensures that assistance to families is carried out with quality.

In a survey conducted in western Paraná, nurses reported that service to users tends to be limited when work is not performed by all team members. Thus, everyone who makes up the FHS team needs to act mutually and cooperatively so that care is longitudinal ${ }^{(12)}$. In this sense, the FHS could count on the participation of the Family Health Support Center, to propose care actions directed to children with special needs for multiple, complex and continuous care, as well as to their families.

The home visit allows professionals to know the family's socioeconomic context, their home care practices and the needs for intervention, support or guidance. Thus, they can prepare the family for a more effective and less arduous activity and promote the health of all family members ${ }^{(13)}$.

A study that aimed to understand how the accessibility of children with disabilities in primary health care is, from the perspective of the professionals from the FHS team, found the lack of transportation as one of the difficulties faced by the team to carry out home visits ${ }^{(14)}$. This difficulty, however, does not justify the fact that such families are not located and assisted in their needs. 
The poor awareness of health professionals about the operation and activities carried out in institutions that provide specialized monitoring to these children, such as the Associação Norte Paranaense de Reabilitação (ANPR), in Maringá-PR is highlighted ${ }^{(15)}$. In practice, these institutions end up taking responsibility for the care and monitoring of the health and development of CSHN, including activities in the pedagogical field.

The guidance and monitoring of the general health of the child and their families must be carried out by the primary care services, and it is up to the professionals of the FHS team to know the demands of the child's care, as well as their monitoring needs to prevent diseases. However, these professionals are unprepared for the care of children with disabilities, such as the assistance necessary referrals for therapies that contribute to their development ${ }^{(14)}$.

Also, the information they send to the family is not always compatible with their needs or degree of understanding, making them anxious, confused and with the feeling of being disrespected, which contributes to not being able to take actions or make decisions in the face of demands child care ${ }^{(8)}$. As of 2008, the Chilean Society of Pediatrics began to use the terms Niños y adolescentes com necessidades especiales de atención em salud (NANEAS) instead of the term chronic illness ${ }^{(16)}$. In this sense, authors believe that special attention from the public health system is necessary, developing health care at the primary, secondary and tertiary levels, respectively, seeking to ensure comprehensive health care for this group and magnify the use of the features available in the health network ${ }^{(16)}$.

According to this model, $\mathrm{PHC}$ teams are responsible for assisting children who need assistance considered to be of low technology - those who have a stable clinical condition, with families equipped to provide care. CSHN who need assistance considered to be of medium technology - stable, but who require specific care and are committed to carrying out their daily activities - must be followed up by the secondary health level, who are directed to a health reference center and accompanied by a family health doctor. On the other hand, children that demand care of high technological density, depend on tertiary care, requiring assistance from a multidisciplinary team. Thus, the model proposes that there is a coordination of the care provided to children and families, highlighting the nurse as an articulator ${ }^{(16)}$.

In Brazil, support networks for children with special health needs are fragmented and weak ${ }^{(17)}$. Public support policies specific to this population could be implemented if there were knowledge of the number of children in the country, if the families were enrolled and systematized in the health services and if there was effective communication between the support networks. In this way, when the child was discharged from the hospital, he/ she would be immediately referred to the primary care service, which would be responsible, together with the family, for the continuity of care at home.

A study carried out in southern Brazil showed that health care networks need to be integrated and articulated to better serve children with special health needs, as PHC is unaware of the needs of the child's chronic condition. This sometimes hinders preventive measures from being designed and implemented to avoid complications that cause the repeated hospital readmissions that affect these children ${ }^{(4)}$.
In Canada, health care and rehabilitation institutions seek to meet the demands of children with special healthcare needs and their families to support the therapeutic plan based on FamilyCentered Care ${ }^{(18)}$. Thus, this approach recognizes the family as the main holder of care for the sick person and advocates that it influences on the health of the person being cared for. This model recommends the inclusion and participation of the family in the elaboration and implementation of care plans for the sick family member, in addition to considering them the protagonist of care, giving them autonomy to decide what their needs are. Besides, it assists to all members of the family system, preventing overload and future injuries ${ }^{(8)}$.

In Brazil, the Home Care Service (HCS) acts as a complementary aid for hospitalization, by training caregivers to carry out activities with the sick person and to expand the autonomy of users, with the support of Multiprofessional Home Care Teams and Multiprofessional Support Teams ${ }^{(19)}$. However, carrying out this service is still restricted to a few locations in the country and, in many areas, children and adolescents are not included in the HCS.

$\mathrm{PHC}$ can be an important ally of families of CSHN, considering their potential to play the role of organizer of the care network and coordinator of care ${ }^{(7)}$. Still, it is possible to develop familycentered care, promoting the bond between the family-team to ensure longitudinal care.

\section{Limitations of the Study}

We highlight as a study limitation, the fact of presenting the report of the difficulty to locate/find children with special healthcare needs in only four Brazilian municipalities. However, as these are located in different states and regions of Brazil, it is inferred that this situation may be similar in other scenarios.

\section{Contributions to Health and Public Policies}

We expect this report will contribute to giving visibility of CSHN and their families in the context of primary care, as well as their care demands in official rates and for the implementation of public policies. With this visibility, it is expected that the chronification rates of these children's health status and the rates of frequent hospital readmissions may be reduced.

\section{FINAL CONSIDERATIONS}

The experience of an active search for children with special healthcare needs in $\mathrm{PHC}$ in four municipalities in different regions of the country showed that these, in their majority, are little known by the professionals who work with this type of assistance and, therefore, do not appear in statistics based on the reality of these services. In this document, the use of the word (in)visibility in the dialectic thinking is highlighted, as it is believed that CSHN, who are although visible to $\mathrm{PHC}$ services, are often made invisible by the feeling of not belonging and the search for specialized services, as reported by families themselves.

Thus, in practice, there is a kind of transfer of responsibility for the care and monitoring of these children's living and health conditions to specialized and rehabilitation institutions or even 
by private health plan operators. This favors the unfamiliarity of the care demands of this group and the appreciation of care centered on disease and rehabilitation, in contrast to the longitudinal care, one of the attributes of primary health care. This way, it is concluded that the integrality of the actions and the guarantee of continuity of care constitute challenges to be overcome by the families of CSHN, since they access the PHC network at the time of diagnosis and, after, they have not ensured the continuity of follow-up in health adequately, as PHC understands that this child needs follow-up in specialized services, often geographically distant from their homes.

The implementation of actions in a systematic way with records and monitoring of these children will enable families to have greater access to primary care services and even greater resolution. However, for this to occur, it is necessary that health professionals, especially those who assist in $\mathrm{PHC}$, are committed to recognizing who these children are in their territory and are concerned with offering them qualified care. Their health care needs must be known, as well as a link with families and accountability to effectively follow-up these children in favor of comprehensive care.

\section{FUNDING}

CAPES - Coordenação de Aperfeiçoamento de Pessoal de Nível Superior. Master's scholarship for the second author 2014/2015.

\section{REFERENCES}

1. Mcpherson MG, Arango P, Fox H, Lauver C, Mcmanus M, Newachek PW, et al. A new definition of children with special healthcare needs. Pediatrics [Internet]. 1998[cited 2015 Sep 3];102(1):137-40. Available from: https://www.ncbi.nlm.nih.gov/pubmed/9714637

2. Ministério da Saúde (BR). Secretaria de Atenção à Saúde. Departamento de Atenção Básica. Política Nacional de Atenção Básica. Brasília: Ministério da Saúde; 2012.

3. Mendes EV. O cuidado das condições crônicas na Atenção Primária à Saúde: o imperativo da consolidação da Estratégia Saúde da Família. Brasília: Organização Pan-Americana da Saúde; 2012 [cited 2016 Mar 15]. Avaliable from: http://www.saude.go.gov.br/public/media/1lUN5g HxOAAGWd/18446212121840542550.pdf

4. Silveira A, Neves ET. Vulnerability of children with special health care needs: implications for nursing. Rev Gaúcha Enferm. 2012;33( 4 ):17280. doi: 10.1590/S1983-14472012000400022

5. Okido ACC, Zago MMF, Lima RAG. Care for technology-dependent children and their relation ship with the healthcare systems. Rev Latino Am-Enfermagem. 2015; 23(2):291-298. doi: 10.1590/0104-1169.0258.2554

6. Dias BC, Arruda GO, Marcon SS. Family vulnerability of children with special needs of multiple, complex and continuous care. Rev Min Enferm. 2017; 21:e-1027. doi: 10.5935/1415-2762.20170037

7. Okido ACC, Cunha ST, Neves ET, Dupas G, Lima RAG. Technology-dependent children and the demand for pharmaceutical care. Rev Bras Enferm. 2016; 69(4):718-724. doi: 10.1590/0034-7167.2016690415i

8. Barbosa MAM, Balieiro MMFG, Pettengill MAM. Family-centered care in the context of children with disabilities and their families: a reflective review. Texto Contexto Enferm. 2012;21(1):194-99. doi: 10.1590/S0104-07072012000100022

9. Arrué AA, Neves ET, Magnago TSBS, Cabral IE, Gama SGN, Hökerberg YHM. Tradução e adaptação do Children with Special Health Care Needs Screener para português do Brasil. Cad Saúde Pública. 2016;32(6):e00130215. doi: 10.1590/0102-311X00130215

10. Nogales JV. Afrontamiento de la muerte de un niño: los cuidados pediátricos paliativos desde la Atención Primaria. Rev Pediatr Aten Prim. 2015;17:171-83. doi: 10.4321/S1139-76322015000300022

11. Machado LM, Mattos KM, Colomé JS, Freitas NQ, Sangoi TP. Family health strategy: the perception of community health agents concerning their work. Cienc Cuid Saude. 2015 14(2):1105-12. doi: 10.4025/cienccuidsaude.v14i2.22612

12. Baratieri T, Marcon SS. Longitudinality of care in nurses' practice: identifying the difficulties and perspectives of change. Texto Contexto Enferm. 2012; 21(3):549-57. doi: 10.1590/S0104-07072012000300009

13. Roecker S, Baratieri T, Sanches PBC, Marques FRB, Teston EF, Marcon SS. Family experience and adaptation to stroke and role of an assistance project. Acta Sci Health Sci. 2012; 34(SE): 277-85. doi: 10.4025/actascihealthsci.v34ispec.10425

14. Rosário SSD, Fernandes APNL, Batista FWBB, Monteiro Al. The accessibility of children with disabilities to primary healthcare service. Rev Eletr Enf . 2013;15(3):740-6. doi: 10.5216/ree.v15i3.19272

15. Dias BC, Ichisato SMT, Marchetti MA, Neves ET, Higarashi IH, Marcon SS. Challenges of family caregivers of children with special needs of multiple, complex and continuing care at home. Esc Anna Nery. 2019;23(1):e20180127. doi: 10.1590/2177-9465-ean-2018-0127

16. Cano JCF, Calvo ML, Zamora NR, Anguita MEA, La Paz MC, Yañez SB, et. al. Modelo de atención y clasificación de Niños y adolescentes con necesidades especiales de atención en salud-NANEAS: recomendaciones del Comité NANEAS de la Sociedad Chilena de Pediatría. Rev Chil Pediatr. 2016;87(3):224-32. doi: 10.1016/j.rchipe.2016.03.005

17. Zamberlan KC, Neves ET, Silveira A, Paula CC. The family care of children with special health care needs in the community context. Cienc Cuid Saude. 2013;12(2):290-7.doi: 10.4025/cienccuidsaude.v12i2.21758

18. Leal RJ, Cabral IE, Perreault M. Experiência Brasil-Canadá no cuidado social e na saúde da criança com necessidades especiais: aproximações 
e distanciamentos. 2010;10(1-2):95-119. doi: 10.15210/interfaces.v10i1.7074

19. Rossetto V, Toso BRGO, Rodrigues RM, Viera CS, Neves ET. Development care for children with special health needs in home care at Paraná Brazil. Esc Anna Nery. 2019;23(1):1-10. doi: 10.1590/2177-9465-EAN-2018-0067 